\title{
名古屋大学電子機械工学科における メカトロニクス教育
}

\section{加藤 仁 ${ }^{* *}$ 堤 成晃 ${ }^{* *}$}

Key words mechatronics, education, curriculum, undergraduate course, graduate course

\section{1. 学 科 の概 要}

急激な発展を遂げつつある先端技術に的確に対応て きる能力をもった技術者や研究者を育成することは, 大学・教育機関における重要な課題となっている。特 に, 機械工学に電子工学を融合させた電子機械工学 〈いわゆるメカトロニクス〉に対する期待と要望は大 きいように思われる。このような要請にこたえて, 昭 和 57 年に国立大学としてはじめて, 名古屋大学工学部 に電子機械工学科か創設された。

現在, 本学科には, 電子機械基礎理論, 電子機械応 用設計, 超精密加工, 電子機械計側, 集積機械工学の 5 つの講座が設けられて括り, 学生定員は 40 名となっ ている。

学生は, 入学後の 2 年間は教養部に属し, 他学部の 学生とともに一般教養科目, 外国語, 工学の基礎科目 などを受講する。 2 年生からは学部における専門科目 の一部か開講され，4年生てはそれぞれの講座に配属 されて各教官の指導のもとに卒業論文を作成す る.

昭和 61 年 3 月には, 第 1 回の卒業生を送り出 す段階となり, これに伴って大学院に電子機械 工学専攻課程か新設された。

\section{2. 学部における教育}

学部におけるカリキュラムは, 創設当初から 若干の改訂を経て現在に至って抒り, 必修 28 科 目 595 単位, 選択 44 科目 785 単位によって構 成されている. 卒業のためには, 計 86 単位以上 を修得しなければならない。

* 原稿受付 昭和 61 年 4 月 2 日

** 正 会 員 名古屋大学工学部 (名古屋市千種区不 老町)

\section{1 必修科目}

工学部共通の数学, 力学を含め, 基礎として表 1 の ような必修科目を課している。学科の性格上, 備考欄 にも記したと扣り, 電気・電子工学の基礎と機械工学 の基礎は欠かせないものと考える。ことに, 社会的要 請か,「機械の原理・特性に精通した, 設計・開発のて きるメカトロニクス技術者」の育成にあることを配虑 し，これを反映させた内容になっている。

したかって, 表 1 のすへてか電子機械工学の基礎と して必須のものてあることを強調したいか, いわゆる メカトロニクスか前面に浮上した科目としては，狭義 の電子機械工学基礎の欄に記したものかあり, また, 設計製困，実験実習の一部にもそれらに関連した課題 か含まれている、講義学科目の内容については, 科目 名によって打拈よその察しかつけられると思われるの て多くを述へないか, 設計基礎論, 電子機械設計ノス テムには CAD, CAM, CAEか含まれており, 電子機 械テハイス工学第 1 ではマイコンに関連した事項が講 表 1 学部必修科目

\begin{tabular}{|c|c|c|}
\hline 科 & 備 & 考 \\
\hline $\begin{array}{l}\text { 数学及ひ数学演習第 } 1 \text {, 数学及ひ数学演習第 } 2 \text {, } \\
\text { 力学及び力学演習第 } 1 \text {, 力学及び力学演習第 } 2\end{array}$ & 物理系 & \\
\hline $\begin{array}{l}\text { 電磁気工学, 電気回路第 } 1 \text { 及ひ演習, 電気回路第 } \\
2 \text { 及び演習, 電子回路論第 } 1 \text {, 電子回路論第 } 2\end{array}$ & $\begin{array}{l}\text { 電気・電子工 } \\
\text { 学基礎 }\end{array}$ & $\begin{array}{l}\text { 電 } \\
\text { 子 }\end{array}$ \\
\hline $\begin{array}{l}\text { 機械運動学, 材料力学第 } 1 \text { 及ひ演習, 振動工学第 } \\
1 \text { 及ひ演習, 流体工学第 } 1 \text { 及ひ演習, 熱工学第 } 1 \\
\text { 及ひ演習, 精密加工学 }\end{array}$ & 饫基礎 & T \\
\hline $\begin{array}{l}\text { 計算機工学第 } 1 \text {, 電子機械制御工学第 } 1 \text { 及ひ演習, } \\
\text { 電子機械計測, 材料物性, 設計基礎論, 電子機械 } \\
\text { 設計ノステム, 電子機械テハイス工学第 } 1 \\
\end{array}$ & $\begin{array}{l}\text { 狭義の電子機 } \\
\text { 械工学基礎 }\end{array}$ & \\
\hline $\begin{array}{l}\text { 電子機械工学設計製図第 } 1 \text {, 電子機械工学設-叶製 } \\
\text { 四第 } 2 \text {, 電子機械工学設計製図第 } 3 \text {, 電子機械工 } \\
\text { 学実験及ひ央習第 } 1 \text {, 電子機械工学実験及ひ実習 } \\
\text { 第 } 2 \text {, 電子機械工学実験及ひ㬰習第 } 3\end{array}$ & $\begin{array}{l}\text { 設計製区, 実 } \\
\text { 験実習 }\end{array}$ & \\
\hline
\end{tabular}


義されている，設計製図では，歯車，ウインチ， 内燃機関などの設計製図に加えて, 内燃機関の電 子制御噴射装置などを例題としている。また，実 験実習に拈いて，その対象にメカトロニクスの性 格が強く表れているものを挙げると次のような テーマがある。すなわち，NC 旋盤による加工実 験，長さの絶対測定㧊よび比較測定，アナログお よびディジタル IC 回路, 磁気回路, センサと $\mathrm{AD}$ DA 変換，モータの位置および速度制御，レーザ マイクロプローブ，ロボット，マイコン（基本構 成, I/O 処理, 割込み処理, $\mathrm{XY}$ Yコーダ図形出 力), サーボ弁・油圧モータ系のマイコン制御, $\mathrm{CAD} / \mathrm{CAM}$ ，などがある。これらのほかのテーマ では, 実験機器の制御や計測のかなりの部分に電 子機器が導入されている。

上記の講義および実験には，電子機械工学科所 属の教官はもちろん，機械学科および機械工学第 2 学科所属の教官も多数投入され, 協力態勢のも とで教育が行われている。

\section{2 選択科目}

選択科目では, 工学部共通の応用物理学第 1 , 同第 2 , 同実験などのほか, 機械工学（材料力学, 振動工学, 流体工学, 熱扣よび伝熱工学, 生産加工㧊よび塑性加 工学)，計算機・情報工学，計測，デバイス，材料・物 性, システムなどに関連するものが幅広く開講されて いる、詳細は表 2 のようであるが，その中には，情報 処理基礎論, 情報伝送基礎論, 情報処理, 電子機械情 報工学, 超精密加工学, 機械加工システム, センサ及 び計測, 電子機械デバイス工学第 2 , 集積機械工学, 集 積機械材料学, 電子機械応用, 応用電子論, などが含 まれており，対象機器の本質をよく理解させるととも に,メカトロニクスに関するセンスを身につけさせる 配慮が加えられている。

また，他学科と同様に，学外実習，工場見学があり， 学生のほとんど全員が参加している。工場見学では, $\mathrm{CAD} / \mathrm{CAM}, \mathrm{IC}$ 製造用機器, FA システムなどの実情 表 2 学部選択科目

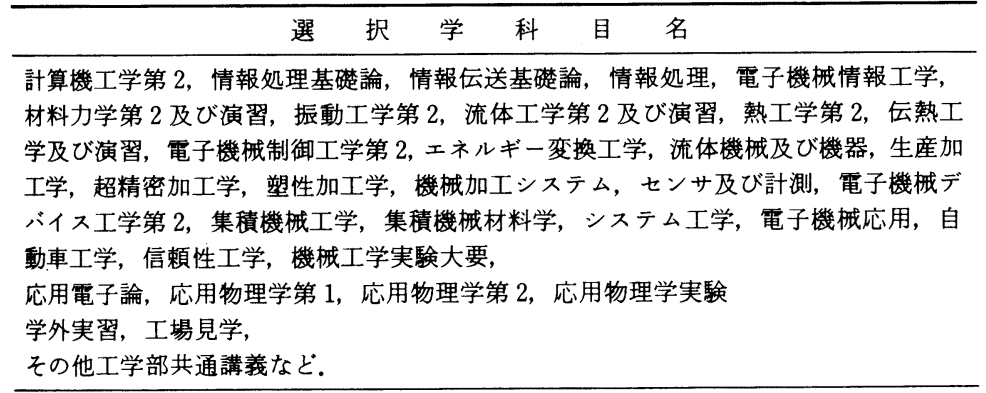

表 3 大学院博士・前期（修士）課程授業科目

\begin{tabular}{|c|c|c|}
\hline 輪 & 論 & 演 \\
\hline $\begin{array}{l}\text { 電磁気工学輪講 } \\
\text { 計算機工学輪講 } \\
\text { 固体力学輪講 } \\
\text { 制御工学輪講 } \\
\text { 振動工学輪講 } \\
\text { 流体工学輪講 } \\
\text { エネルギー変換工学 } \\
\text { 輪講 } \\
\mathrm{CAD} / \mathrm{CAE} \text { 輪講 } \\
\text { センサ及び計測輪講 } \\
\text { 精密加工学輪講 } \\
\text { 超精密加工学輪講 } \\
\text { 集積機械工学輪講 }\end{array}$ & $\begin{array}{l}\text { 電磁気工学特論 } \\
\text { 集積回路工学特論 } \\
\text { 計算機工学特論 } \\
\text { 機能材料学特論 } \\
\text { 固体力学特論 } \\
\text { 制御工学特論 } \\
\text { 振動工学特論 } \\
\text { 流体工学特論 } \\
\text { エネルギー変換工学特 } \\
\text { 論 } \\
\text { CAD/CAE 特論 } \\
\text { センサ及び計測特論 } \\
\text { 精密加工学特論 } \\
\text { 超精密加工学特論 } \\
\text { 集積機械工学特論 } \\
\text { 電子機械デバイス工学 } \\
\text { 特論 } \\
\text { ロボット工学特論 } \\
\text { 真空機器工学特論 } \\
\text { 電子機械情報工学特論 } \\
\text { 電子機械工学特論第 } 1 \\
\text { 電子機械工学特論第 } 2 \\
\text { 電子機械工学特論第 } 3\end{array}$ & $\begin{array}{l}\text { 計算機工学演習 } \\
\text { 固体力学演習 } \\
\text { 流体工学演習 } \\
\text { エネルギー変換工学 } \\
\text { 演習 } \\
\text { CAD/CAE 演習 } \\
\text { センサ及び計測演習 } \\
\text { 精密加工学演習 } \\
\text { 集積機械工学演習 }\end{array}$ \\
\hline
\end{tabular}

にも接する機会を与兄，かなりの教育的効果をあげて いる.

\section{3. 大学院における教育}

大学院博士・前期 (修士) 課程では, 以下に述べる 学科目のらちから 15 科目 (30 単位) 以上を修得し, か つ, 研究指導を受けた上, 修士論文を提出して学位試 験に合格しなければならない。

大学院における学科目種別は, 輪講, 特論, 演習よ りなり，現在それぞれについて，12，21，8科目の開講 が予定されている。詳細は表 3 のと打りで，学科目編 成の基本方針は学部の場合と同じであるが，ょり高度 の専門知識の修得と研究開発能力の育成を目指すもの となっている.

\section{4.おわりに}

本学科は発足してから日も浅い ため，基盤，教育環境なども十分 に固まったとは言い難い。カリ キュラムについても，現状は上に 述べたと打りであるが，諸賢のご 叱責をいただくことによって修正 を加えてゆきたいと考えている。 ことに，企業に所属する会員諸氏 のご意見がいただければ幸いであ る。 